Információközvetítés és közösségépítés - multifunkciós könyvtári hálózatok.

Szerk. Kiszl Péter, Németh Katalin. Budapest, ELTE BTK

Könyvtár- és Információtudományi Intézet. 2020. 95-102.

\title{
A TÖBBNYELVÜ TEZAURUSZOK KIALAKULÁSA TÖRTÉNETI NÉZŐPONTBÓL ÉS A TEZAURUSZOKRA VONATKOZÓ SZABVÁNYOK, IRÁNYELVEK
}

\author{
DULA MARINA
}

\section{TARTALMI ÖSSZEFOGLALÓ}

A tanulmány röviden bemutatja Roget, Batten, Mooers, Luhn és Taube azon elméleteit, amelyek meghatározták a tezauruszok kialakulását. Az anyag az alfabetikus tezauruszok korai dominanciáját tárgyalja a TEST, az ENSZ makrotezaurusza és a MeSH példáin keresztül. Röviden összefoglalja a facettás tezauruszok megjelenési formáira vonatkozó ismereteket, kiemelve Ranganathan és Bliss munkásságát, illetve részletezi Schmitz-Esser és Jorna újszerü struktúráit. A dokumentum második felében összegyüjtésre kerültek Kelet-közép Európa és Nyugat-Európa többnyelvü tezauruszokra vonatkozó szabványai és irányelvei, esetenként nemzeti szabványokat bemutatva, valamint az NTMIR az UNESCO és az IFLA gondozásában megjelent dokumentumokat alapul véve.

\section{A többnyelvü tezauruszok kialakulásának elözményei}

A tezaurusz görög eredetű szó, mely az angol nyelvterületen először 1736-ban jelent meg, az Oxford szótár rövidített változatában. A kifejezés jelentése akkoriban a tudás kincsestárát vagy az ismeretek enciklopédiáját jelölte. A leghíresebb - ebben az értelemben vett tezaurusz - Peter Mark Roget gondozásában készült el 1852-ben Thesaurus of English Words and Phrases címen, amelynek felépítése alapvetöen alfabetikus volt, de szisztematikus témakörök szerinti elrendezés is szerepelt benne. A témakörök szerinti felbontásban az egymáshoz kapcsolódó kifejezésekből Roget csoportokat alkotott, amelyeket egy-egy nagyobb fogalmi kategória alatt helyezett el. A kategóriák számozását az egyes számmal kezdte, egész számokkal haladt növekvő sorrendben, ezeken belül nem alkalmazott további tagolást. A kategória-csoportokban Roget külön bekezdésekben helyezte el az egymáshoz szorosabban kapcsolódó fogalmakat. Mindig az általánostól haladt a specifikus felé, az egy kategóriához kapcsolódó kifejezések felsorolását fönevekkel kezdte, igékkel folytatta, majd a kapcsolódó melléknevekkel zárta. A tezaurusz második részében az alfabetikus elrendezés tette lehetővé a fogalmak egyszerü visszakeresését, amely tartalmazta, hogy a szisztematikus rész melyik oldalán található meg az adott kifejezés. ${ }^{1}$ 


\section{Dula Marina}

Egy évszázaddal később a tezaurusz kifejezést már az információ visszakeresésre használt tárgyszólisták megnevezésére alkalmazták, azonban egészen idáig a fogalom többféle megközelítése volt használatos. Kezdetben a tezaurusz többeknél, így Batten és Mooers korai elméleteiben is manuális posztkoordinált rendszerként jelent meg. Ebben a struktúrában az indexelő kifejezéseket anélkül rendelik hozzá a dokumentumhoz, hogy figyelembe vennék a szintaxist, ellentétben a prekoordinált rendszerekkel, ahol az indexelö által összekapcsolják a kifejezéseket egy állandó karaktersorozatba. A posztkoordinált rendszerek sajátossága, hogy a kereső, a kifejezések bármilyen kombinációjával megtalálhatja a releváns elemeket. ${ }^{2}$

A továbbiakban a tezauruszt a posztkoordináltság helyett az információ-viszszakeresés szempontjából határozták meg. A szakemberek között egyetértés van abban, hogy az információ-visszakereséssel összefüggésben Peter Luhn az International Business Machines Corporation (IBM) munkatársa használta elöször a kifejezést. Ez az aspektus már jól dokumentált, nemcsak Gilchrist, hanem Vickery, Lancaster és Roberts is ebben a szemléletben készítette el munkáit. Az első tezauruszt valójában egy információ-visszakereső rendszer szókincsének ellenőrzésére használták, amelyet a Du Pont Szervezet (E. I. Dupont de Nemours and Company) fejlesztett ki 1959-ben. Azonban az első már széles körben is hozzáférhető ellenőrzött szótár az Amerikai Hadászati Müszaki Információs Központ gondozásában megjelent Armed Services Technical Information Agency (ASTIA) tezaurusza volt, amelyet 1960-ban adtak közre. Az ASTIA-ban már egy jóval átgondoltabb, részletesebb rendszerbe állították a kifejezéseket, illetve a kifejezések közötti kapcsolatok egyes típusait is feltüntették. A tezaruszban három szinten különböztettek meg fogalmakat: témakategóriákat, deszkriptor-csoportokat és deszkriptorokat is szerepeltettek. Nem sokkal ezt követően 1961-ben jelent meg a Vegyészmérnökök Amerikai Intézetének (American Institute of Chemical Engineers) mikrotezaurusza, a Chemical Engineering Thesaurus. ${ }^{3}$

A tezauruszok az 1950-es években többféle „formát öltöttek”. Ebben a legnagyobb szerepet Mortimer Taube Uniterm rendszere játszotta. Taube rendszerében a dokumentum szövegéből kiválasztott egytagú, uniterm kifejezések jellemezték a tartalmat, amelyekkel viszont problémák merültek fel a szinonimák, a homonimák és az azonos alakú szavak összefüggésében. Az unitermek gyakran eltérő jelentéssel bírtak a szövegkörnyezettől, az alkalmazástól, vagy a nézőponttól függően. A rendszerből hiányoztak a minősítők, ezért a fogalmak közötti speciális különbségek sem voltak kellően kifejezve. Ezért például az „electrical insulation” (elektromos szigetelés) összetétel különbözik a „thermal insulation” (hőszigetelés) kifejezéstől, de ezek közös része, az egytagú „insulation” alapján nem lehetett a jelentésbeli eltérés árnyalatát érzékelni. Mivel a Taube által létrehozott rendszer mellőzte az ellenőrzés bármilyen formáját, így az unitermek is alkalmatlanok voltak az egyedi indexelés és a velük való keresés biztosítására. Az uniterm struktúra tehát ebben a formájában nem maradt fenn sokáig, annak ellenére, hogy az uniterm rendszer elméleti szerepe és jelentősége máig ható. ${ }^{4}$ 
A Taube által kivitelezett struktúrát végül felváltották azok a szótárak, amelyek már jelentős számú összetett kifejezést is tartalmaztak. Ezekben a korai fogalomtárakban már elkezdték ellenőrizni a szinonimákat, a homonimákat és megjeleníteni a kifejezések közti hierarchikus és asszociatív kapcsolatokat is. A hatvanas években váltak szembetűnővé a különbségek a hagyományos tárgyszólisták és a fejlődő tezauruszok között. Bár a tárgyszólistákban is jellemzőek voltak a „Lásd” és a „Lásd még” hivatkozások, de fontos eltérés volt, hogy a tárgyszólistákkal kapcsolatban hiányosak voltak a pontos szabályok a szókincs ellenőrzésére és a fogalmak közötti kapcsolatok kifejezésére. Ebben az időszakban minden tezaurusz kifejezéseket sorolt fel alfabetikus sorrendben. A szabványos forma 1967-ben alakult ki, amikor a Thesaurus of Engineering and Scientific Terms (TEST) megjelent a Mérnökök Közös Tanácsának gondozásában és helyébe lépett a Thesaurus of Engineering Terms of the Engineers Joint Council korábbi verziójának. Clarke szerint a TEST-ben már jelen voltak azok a funkciók, amelyek a következő harminc év és a ma tezauruszait egyaránt jellemzik, ideértve az ekvivalenciákat, valamint a hierarchikus és az asszociatív kapcsolatokat is. ${ }^{5}$

\section{Az alfabetikus tezauruszok korai dominanciája}

A korai tezauruszok domináns eleme volt a deszkriptorok és a nemdeszkriptorok alfabetikus megjelenítése. A téma áttekintése, illetve a szisztematikus megjelenítés, - ha egyáltalán létezett, - csak másodlagos fontosságú volt ebben az időszakban. Egy részletes, minősített elrendezést, mint amilyen az enumeratív osztályozási rendszerekben van jelen, túl bonyolultnak és elavultnak tartottak ahhoz, hogy szerepet kapjon az információ-visszakeresésben. Ennek ellenére néhány tezaurusznak voltak kezdetleges szisztematikus szakaszai, amelyek tág témakategóriákból álltak. A TEST-ben a kifejezések betürendes felsorolásával - meglehetősen jelentős terjedelemben -, százkilencven oldalon keresztül foglalkoztak, illetve külön listán szerepeltették a csúcsdeszkriptorokat, ahol feltüntették a szükebb értelem minden szintjét. Ezen kívül a TEST-nek volt egy szisztematikus fejezete, ahol huszonkét tárgyi kategóriát különböztettek meg, ezen belül egy hierarchia szinttel lejjebb alcsoportok helyezkedtek el. A tezaurusz összes deszkriptorát azonban csak az alfabetikus sorrendben tüntették fel, a szisztematikus rész rovására. ${ }^{6}$

Sok tezauruszt készítettek el nemzetközi szervezetek, a legismertebb ilyen makrotezaurusz elöállítója Jean Viet volt, aki az Egyesült Nemzetek Szervezetének (ENSZ) makrotezauruszában már sokkal kifinomultabb tárgyi csoportosításokat szerepeltetett. Müvében a deszkriptor-csoportok megjelenítésére föcsoportokat alkalmazott, amelyek alcsoportokra bomlanak, ezeken belül pedig az alcsoportok deszkriptorai további klaszterekre tagolódnak. A tezauruszok ezen formájában a szisztematikus rész jellemzően alárendeltje az alfabetikus szekciónak, ahelyett, hogy ez képezné az ellenőrzött szótár velejét. Vagyis a fölé-, alárendelt és kapcsolódó kifejezések csak a betürendes megjelenítésben vannak feltüntetve. ${ }^{?}$ 


\section{Dula Marina}

A betűrend dominanciája alól kivételt képzett a Medical Subject Headings (MeSH), amely az amerikai Országos Orvostudományi Könyvtár (National Library of Medicine - NLM) gondozásában jelent meg az 1960-as években. Az orvosi tezauruszban a betürendes rész nem felelt meg a ma szokásos tezaurusz elrendezésnek, mivel nem mutatta a fölérendelt és az alárendelt kifejezéseket, nem tartalmazott magyarázatokat, szinonimákat és kapcsolódó kifejezéseket. Az alfabetikus rész elsősorban a gráfok mutatójaként szolgált. A $M e S H$-ben a gráfok segítségével azonban kiterjedt hierarchiába rendezve helyezték el a deszkriptorokat, egy témakörön belül általában tíz, illetve néhány helyen még ennél is több szintre bontva a kifejezések reprezentálását. Az ábrázolás során alkalmazott gráfok pontosan kifejezték a hierarchia szinteket, és lehetővé tették, hogy a kereső úgynevezett „robbantott” keresést végezzen, ami az adott deszkriptorral indexelt tételek és a kifejezés alatt elhelyezkedő szűkebb értelmü változatok megtalálását és később letöltését is lehetővé tette. Éppen ezért ezt a típusú grafikus megjelenítést a mai napig alkalmazzák a tezauruszok szótári részében. ${ }^{8}$

\section{A facettás tezauruszok megjelenési formái}

Később a facetta analízis alapvetően befolyásolta a tezauruszok fejlödését. Körülbelül egy évtizeddel a tezauruszok kialakulása elött $S$. R. Ranganathan kifejlesztett egy innovatív osztályozási technikát. Gondolatai a korai ötvenes évekre az Egyesült Királyságban is elterjedtek. Az osztályozás nagyjai közül kikerült ezen új technika kedvelői hozták létre Londonban a Classification Research Groupot (CRG) azért, hogy ott megosszák egymással ötleteiket és különböző facettás osztályozási rendszereket dolgozzanak ki számos speciális területen. Az egyik ilyen egyedi, a CRG által kivitelezett munka az angol Elektrotechnikai Társaság Könyvtárának készített rendszer volt, amelyet később, index alkalmazása helyett - alfabetikus tezaurusszal támogattak az élvonalbeli információ visszakeresés érdekében. Az így létrehozott tezaurusz 1969ben jelent meg, ez volt az első olyan ellenőrzött szótár, amely facetta analízist is használt. A Thesauro facetet egy sor hasonló elven alapuló tezaurusz követte, ezek közé tartozott az UNESCO Tezaurusz első kiadása, a BSI ROOT Tezaurusz és a Nemzetközi Menekültügyi Tezaurusz. A tezauruszok ezen változataiban facetta analízist használtak a kifejezések közötti kapcsolatok megállapítására. Egyidejűleg építették ki a hierarchikus és asszociatív kapcsolatokat, valamint Bliss Bibliográfiai besorolása is nagy hatással volt a fogalmak sorrendjére. A facettás tezauruszok egy másik változatában az ismeretek területe a Ranganathan által használt facettákra van felosztva, melyek nem a tárgy mezőben jelennek meg. Ide sorolható a Construction Industry Thesaurus és az Art \& Architecture Thesaurus. ${ }^{9}$

\section{Újszerü megoldások}

Mára a tezauruszok kialakításának egészen újszerű módszereit alkalmazzák a szakemberek. Ezek az elektronikus szótárak saját területükön legyőzik a fogalomtárak 
legnagyobb nehézségeit. Túlmutatnak az alapvető szemantikai viszonyokon a tágabb, a szűkebb és a kapcsolódó kifejezések szempontjából. ${ }^{10}$

A Schmitz-Esser és csapata által 1999-ben Hannoverben kialakított EXPO 2000 tezaurusz, általános ismeretkört ölel fel, öt különböző nyelven, a hierarchikus kapcsolatokban pedig tizenhárom alosztást különböztet meg. Schmitz-Esser újítása, hogy a bizonytalan asszociatív kapcsolatok helyett, bevezetett egy alapvető szemantikai referencia szerkezetet, amely hat fö kategóriát tartalmaz: a fogalom, a név, az esemény, a hely, a szempont, és az idő megkülönböztetéseit, a lexikális hézagokat pedig parafrázisokkal töltötte ki. Így minden deszkriptor egy kétdimenziós rácsszerkezetben kerül elhelyezésre, melynek egyik dimenziójában a tizenhárom hierarchia típus, a másikban pedig a hat alapvető szemantikai referencia található. A SchmitzEsser-féle táblázatos megjelenítésnek az az előnye, hogy általánosságban átláthatóbb és következetesebb a felhasználók számára, vagyis inkább enciklopédikus áttekintést nyújt. Azonban ugyanez az ábrázolás gyakran a nyelvi pontosság rovására megy. ${ }^{11}$

A Jorna által 2001-ben publikált InfoDEFT szintén jó példája a modern kialakításnak. Az InfoDEFT egy három nyelvü, csak az információ-visszakeresés kifejezéseit feltáró elektronikus tezaurusz. Az EXPO 2000-hez hasonlóan az InfoDEFT is öt fö kategóriába sorolja a fogalmakat: dolgok, emberek, tevékenységek, helyek és környezet, azonban az InfoDEFT az EXPO 2000-től eltérően egy facettás alapú fogalomtár. Az InfoDEFT facettái követik a gráfok felépítését, vagyis számos horizontális kapcsolatot tartalmaznak, melyek a fák ágainak felelnek meg. Fontos megjegyezni, hogy Jorna szerint a lexikai hiányosságokat nem szabad elrejteni, inkább fel kell rájuk hívni a figyelmet. Intuitív megközelítésének eredménye, hogy a Schmitz-Esser-féle enciklopédikus áttekintés helyett, az InfoDEFT-ben a kifejezések jelentésének mélyebb megértése valósul meg a különböző nyelveken. ${ }^{12}$

Bár a két tezaurusz jelentősen különbözik, azonban az eltérő szerkezetek kialakítása mindkét esetben indokolt volt. A szakemberek azért hozták létre őket ezekben a differens formákban, mert mára a fogalomtárak alkalmazásának sokfélesége indokolttá tette bizonyos tezaurusz funkciók előnyben részesítését.

\section{A többnyelvü tezauruszokra vonatkozó szabványok, irányelvek}

A tezauruszok kialakításának már a korai „evolúciós” időszakában is voltak szabványaik és irányelveik. Eugene Wall számos problémát küszöbölt ki az alfabetikus tezauruszok kialakításával kapcsolatban. A TEST számos szabályt és konvenciót köszönhet Wall befolyásának, amely egyfajta alapot jelentett a többnyelvü terminológiai szótárak kialakításának kérdéskörében. ${ }^{13}$

Az első tezauruszok megjelenése után az Egyesült Nemzetek Nevelésügyi, Tudományos és Kulturális Szervezete (United Nations Educational, Scientific and Cultural Organization - UNESCO) és a Nemzetközi Tudományos és Müszaki Információs Rendszer 


\section{Dula Marina}

(NTMIR) vezérlete alatt jelentek meg a többnyelvüséget célzó fő iránymutatások. Majd nemzetközi és nemzeti szinten is megkezdődtek a terminológiai szabványosítás céljára készülő szótárak fordítására, többnyelvüsítésére tett kísérletek. Így például 1972-ben adták ki a Német Szövetségi Köztársaságban (NSZK) a Beling, Schuck és Wersig által elkészített módszertani útmutatót az idegen nyelvű tezauruszok német nyelvre fordítására. ${ }^{14}$

\section{Kelet-közép Európa tezaurusz szabványai}

Az NTMIR Többnyelvü információkereső tezaurusz című szabványa és ennek második kiadása is, valójában korábban készült el, mint az UNESCO ugyanezen témában megjelent irányelve vagy az erre vonatkozó Nemzetközi Szabványügyi Szervezet (International Organization for Standardization - ISO) által létrehozott szabvány. 1974ben a Német Demokratikus Köztársaságban (NDK) a még előkészületben lévő NTP MCNTI 15-76 elöírással összhangban már elkészültek az orosz-német/német-orosz nyelvű tezauruszok kidolgozásának irányelvei, majd ennek példájára folyamatosan jelentek meg a kétnyelvü mikrotezauruszok, építésügyi, kémiai és mérésügyi témákban. 1978-ban Magyarországon kiadásra került Ungváry Rudolf Tezauruszfordítási irányelvek címü müve, amely az akkori Kohó- és Gépipari Tudományos Informatikai és Ipargazdasági Központnál készülő hat NTMIR-tezaurusz orosz nyelvű bázistezauruszának fordítási irányelveit tartalmazta. A tezaurusz-szerkesztéssel foglalkozó dokumentumok magyar fordításait az NTMIR normatív-müszaki dokumentumaiból összeállított köteteiben is kiadta. A Szovjetunió megszűnésével azonban az NTMIR is befejezte szakmai tevékenységét, így 1985-ben ugyan még sor került egynyelvü szabványuk magyarországi honosítására, azonban a többnyelvű irányelvek átvétele már nem - azóta sem - történt meg. ${ }^{15}$

Így az MSZ 3418 - bár nemzetközi társainál jóval részletesebben írja le a relációk fajtáit, első és második kiadása is csak az egynyelvü tezauruszokat szabályozza. Tehát nincs többnyelvü tezauruszokkal kapcsolatos magyar szabványunk. Ez többek között azért is sajnálatos, mivel a Kölcsönös Gazdasági Segítség Tanácsa (KGST) államok többnyelvü tezaurusz szabványai megegyeznek az UNESCO irányelvekkel és az ISO szabvánnyal, tartalmukat illetően független szerkesztés eredményei. Az NTMIR szabványai részben tovább öröklődtek hazai szabványunkban, valamint az Orosz Tudományos és Műszaki Információs Intézet, a VINITI keretei között. ${ }^{16}$

Nyugat-Európa tezaurusz szabványai és irányelvei

Derek Austin és Dale nagy hatással voltak a nyugati szabványokra, ők az UNESCO egynyelvü tezauruszaira vonatkozó irányelv első és második kiadásának szerkesztésében is részt vettek, majd az általuk kidolgozott elméleteket később beépítették az egynyelvü tezauruszokra vonatkozó nemzetközi kiadásba, az ISO 2788-ba is. Austin a PRECIS indexelő rendszerrel is foglalkozott, mely egy szövegen belüli szerepet megőrző osztályozási rendszer. Az itt szerzett tapasztalatai alapján a nemzetközi 
A TÖBBNYELVŰ TEZAURUSZOK KIALAKULÁSA TÖRTÉNETI NÉZŐPONTBÓL...

szabványba is átültette az összetett kifejezésekkel kapcsolatos fontosabb szabályait és bevezette a szisztematikus tezaurusz és a facetta analízis fogalmát. ${ }^{17}$

Az egynyelvü tezauruszokra vonatkozó ISO 2788 szabványt először 1974-ben publikálták, majd 1986-ban jelent meg ennek második kiadása. Számunkra ez a kiadvány azért érdekes, mert a többnyelvü tezauruszokra vonatkozó ISO 5964-ben már nem ismételték meg a korábban már az 1974-es szabványban rögzített a többnyelvü rendszerekre is jellemző gondolatokat. A többnyelvű tezauruszokhoz kapcsolódó UNESCO irányelvek kialakítását 1974-ben az International Scientific Symposiumon kezdeményezték, az így megjelent dokumentumot tartjuk hivatalosan a szakterület szabványosítási kiindulópontjának.

1980-ban megjelent az Austin által szerkesztett javított változat, amely 1985-ben a többnyelvü tezauruszok szerkezetére vonatkozó ISO 5964 szabványt eredményezte. Ezeket a nemzetközi szabványokat számos ország fogadta el sajátjának, köztük Franciaország is, ahol már ugyanebben az évben elkészült $A$ relációk jelölése egy és többnyelvü tezauruszokban című szabványuk, később pedig Németország és az Egyesült Királyság is felzárkózott, éppen ezért az Egyesült Királyság alapvetései a BS 5723 és a BS 6723 is megegyeznek az ISO 2788 és az ISO 5964 szabványokkal.

Az ISO két tezauruszokról szóló szabványát 2008-ban felülvizsgálták, kiterjesztették és egyetlen új ISO 25964 szabvánnyá alakították, ami Tezauruszok és interoperabilitás más szótárakkal címen jelent meg. A szabvány első része, a Tezauruszok az információlekérdezéshez egynyelvü és többnyelvű tezauruszra vonatkozó nemzetközi szabványtervezet 2011-ben jelent meg. Míg a szabvány második része, az Interoperabilitás más szótárakkal jelenleg is fejlesztés alatt áll. ${ }^{18}$

Egy másik nemzetközi szervezet, az International Federation of Library Associations and Institutions (IFLA), a tezauruszok kialakításával kapcsolatos irányelveik megalkotásával képviseltette magát a területen. 1992-ben az IFLA egyik munkabizottsága elkészítette $A$ tartalmi feltárás lexikai egységeire vonatkozó szabványtervezetet, amelyben részletesen szabályozták, hogy milyen szerkezetü tételt alkossanak az állományba felvett tárgyszavak és deszkriptorok. 2005-ben az IFLA megjelentette többnyelvű tezauruszokra vonatkozó iránymutatását, majd 2009-ben kiadták ennek átdolgozott változatát. A 2009-es anyagban az IFLA szakemberei könnyen áttekinthető formában foglalták össze azokat az ismérveket, amelyek a többnyelvű tezauruszok szerkezeti elemeire és kialakításuk lehetőségeire vonatkoznak. Így a témában érdeklődők számára, az IFLA 2009-es irányelve fontos kiindulópontként szolgálhat. ${ }^{19}$

\section{Irodalom és jegyzetek}

1. ROGET, Peter M.: Roget's Thesaurus of English Words and Phrases, 1852. 736 p.

2. GILCHRIST, Alan: The thesaurus in retrieval. London, Aslib, 1971. 184 p. 


\section{Dula Marina}

3. AITCHISON, Jean - CLARKE, Stella J. Dextre: The thesaurus. A historical viewpoint, with a look to the future. $=$ Cataloging \& Classification Quarterly, 37. vol. 3-4. no. 2004. 5-21. p. Forrás: https://doi.org/10.1300/J104v37n03_02 [2019. július 1.]

4. UNGVÁRY Rudolf - ORBÁN Éva: Osztályozás és információkeresés 1. Az osztályozás és elmélete. Budapest, OSZK Könyvtártudományi és Módszertani Központ, 2001. 543 p.

5. AITCHISON, Jean - CLARKE, Stella J. Dextre: i. m.

6. HEALD, Heston J.: The making of test. Thesaurus of engineering and scientific terms. Washington, Office of Naval Research, 1967. 176. p. Forrás: https://doi.org/10.21236/ AD0661001 [2019. május. 30.]

7. AITCHISON, Jean - CLARKE, Stella J. Dextre: i. m.

8. Uo.

9. Uo.

10. JORNA, Kerstin - DAVIES, Sylvie: Multilingual thesauri for the modern world. No ideal solution? = Journal of Documentation, 57. vol. 2. no. 2001. 284-295. p. Forrás: https:// doi.org/10.1108/EUM0000000007103 [2019. július 1.]

11. SCHMITZ-ESSER, Winfried: Thesaurus and beyond. An advanced formula for linguistic engineering and information retrieval. = Knowledge Organization, 26. vol. 1. no. 1999. 10-22. p.

12. JORNA, Kerstin - DAVIES, Sylvie: i. m.

13. KROOKS, David A. - LANCASTER, Wilfrid F.: The evolution of guidelines for thesaurus construction. = Libri, 43. vol. 4. no. 1993. 326-342. p. Forrás: https://doi.org/10.1515/ libr.1993.43.4.326 [2019. július 1.]

14. UNGVÁRY Rudolf: A két- és többnyelvü tezauruszok irodalma. Kritikai szemle és annotált bibliográfia. Szerk. Ungváry Rudolf, Orbán Éva, Budapest, OSZK KMK, 1981. 123 p.

15. Uo.

16. SONNENVEND Péter: Hatvanéves a VINITI. = Könyvtári Figyelö, 59. évf. 2. sz. 2013. 315-321. p.

17. AUSTIN, Derek - DYKSTRA, Mary: PRECIS. A manual of concept analysis and subject indexing. London, Bibliographic Services Division, 1984. 397 p.

18. ISO 25964. The international standard for thesauri and interoperability with other vocabularies. International Organization for Standardization, 2011. 96 p. Forrás: http:// www.niso.org/schemas/iso25964/\#summary [2019. május 30.]

19. Guidelines for multilingual thesauri. Hagues, Working Group on Guidelines for Multilingual Thesauri IFLA Classification and Indexing Section, 2009. 30 p. Forrás: http://www.ifla. org/files/assets/hq/publications/professional-report/115.pdf [2019. május 30.]

Dula Marina az ELTE BTK Könyvtár- és Információtudományi Intézetének mesterszakos hallgatójaként 2014-ben a XXXII. Országos Tudományos Diákköri Konferencián Barátné Hajdu Âgnes témavezetésével 2. helyezést ért el könyvtártudományi II. szekcióban a Többnyelvü tezauruszok címü pályamunkájával. Az Országgyülési Hivatal, majd az Isobar Budapest munkatársa. 